\title{
Bone Cancer Pathologic TNM Finding v7
}

National Cancer Institute

\section{Source}

National Cancer Institute. Bone Cancer Pathologic TNM Finding v7. NCI Thesaurus. Code C88423.

A pathologic finding about one or more characteristics of bone cancer, following the rules of the TNM AJCC V7 classification system. The pathologic diagnosis is based on the microscopic examination of tissue, correlated with imaging studies. (from AJCC 7th Ed.) 